\title{
First record of Leopardus colocola (Molina, 1782) in Northern Patagonia, Aysén Region, Chile, and behavioral scent-marking observations
}

\author{
Primer registro de Leopardus colocola (Molina, 1782) en Patagonia Norte, Región de Aysén, \\ Chile y observaciones de comportamiento de marca territorial
}

\section{Calos Castro-Pastene ${ }^{1, *} \&$ Daniel Cross ${ }^{2}$}

${ }^{1}$ Programa de Magíster en Ecología Aplicada, Instituto de Ciencias Ambientales y Evolutivas, Facultad de Ciencias, Universidad Austral de Chile, Valdivia, Chile. ${ }^{2}$ San Vicente 104, Casilla 261, Coyhaique, Chile.

*E-Mail: ccastropastene@gmail.com

\begin{abstract}
Scarce records of Pampas cats exist in the extreme south of Chile (Patagonia). Through camera traps, we captured the first confirmed record of L. colocola in northern Patagonia of Chile. Besides, records of its marking behavior through feces and urine were captured and discussed to understand this poorly known wild cat.

Palabras clave: carnívoro, pajeros, pequeño felino, trampas cámaras.

RESUMEN

Escasos son los registros de gato Colo-Colo en el extremo austral de Chile. Mediante cámaras trampas capturamos el primer registro confirmado de L. colocola en la Patagonia Norte de Chile. Además, se aportan registros de su conducta de marca territorial a través de heces y de orina, los que han sido escasamente documentados para felinos salvajes.
\end{abstract}

Keywords: carnivore, pajeros, small cat, trail cameras.

The Colo-Colo (Leopardus colocola) or Pampas cat is one of Chile's least known wild cat species. This cat has a wide geographical distribution in South America, ranging from north to south from Ecuador to Argentinean Patagonia and from east to west from Brazil to Chile (Nowell \& Jackson 1996). Recently, it has been considered a rare wild cat species in almost all its distribution range (Lucherini et al. 2016). The Pampas cat has great phenotypic variability in all its range, which confuses its taxonomy. The most recent taxonomic review by the Cat Specialist group (Kitchener et al. 2017) establishes seven subspecies with a great genetic difference. Recently, Do Nascimento et al. (2020) has made a new taxonomic proposal for the species but have not been assessed or approved by the IUCN Cat Specialist Group. In
Chile, there are three subspecies: L. colocola colocola; L. C. wolffsohni Garcia-Perea 1994; y L. c. pajeros Desmarest 1816. The subspecies L.c. pajeros presents a distribution mainly in Argentina (Garcia-Perea 1994; Kitchener et al. 2017). Some authors believe that this subspecies would not be present in Chilean Patagonia (Kitchener et al. 2017). Wolffsohn (1908) is the first who refers to the presence of L. colocola at Southern Patagonia in Chile. However, it is not clear the veracity of this record due to color differences and its possible misunderstanding with the sympatric Geoffroy's cat (Leopardus geoffroyi). Indeed, these differences, together with differences in cranial measurements, led Garcia-Perea (1994) to raise it to full species. Johnson et al. (1990) is the first to confirm this species's presence by capture in the southern 
Patagonia of Chile (at a small town located $50 \mathrm{~km}$ to the south of Torres Del Paine). Then, Garcia-Perea (1994) registered this cat from two individuals from Southern Patagonia (in Puerto Prat and Cerro Castillo, based on an individual from a museum and Johnson et al. 1990, respectively). Since that date, no records of $L$. colocola exist in Patagonia in Chile.

The field of study is located close to Ingeniero IbañezPallavicinni's border crossing $(20 \mathrm{~km}$ east from the city of Puerto Ingeniero lbáñez). The vegetation of the zone is Andean temperate grassland of Nassauvia dentata and Senecio portalesianus (Luebert \& Pliscoff, 2018).

Here the first record in Northern Patagonia and the southernmost record of L. colocola in Chile since 1990. We set eighteen camera traps (Stealthcam models STC-G45NGX, STC-G45NGMAX, and STC-DS4K; Browning model BTC5HDX; Rainbowday model DEER CAM and Camtrap model KAMTRAP); We installed five units in front of carnivore's dens, and 13 units in animal trails (based on footprints and other signs). All camera traps were set to record videos for
40 seconds in order to register behavior. The work area is delimited north by latitude $46^{\circ} 14^{\prime} 1^{\prime \prime} \mathrm{S}$, westward $71^{\circ} 48^{\prime} 14^{\prime \prime}$, $\mathrm{W}$, eastward along the Argentine border, and covers $12 \mathrm{~km}^{2}$. To the south, it borders the parallel $46^{\circ} 18^{\prime} 25^{\prime \prime} \mathrm{S}$. Each camera traps is separated from another by a distance of approximately $1 \mathrm{~km}$, except for two cameras facing each other in a cave.

We captured five events of L. colocola, during 6570 trap nights in 12 months. These woes correspond to marking behaviour records related to the use of dens, such as defecation and urine spraying. During the check of camera trap in front of a burrow, we identify feces of $L$. colocola by morphological features (Figs. 1A and 1B). The feces found in the caverns match the description for small wild cats (Palacios 2007; Muñoz-Pedreros 2010). Also, the feces found cannot be confused with the Patagonian skunks' excrement because they differ significantly in their anatomy (Travani et al. 1998; Medina et al. 2009).

In site 3 , we captured L. colocola observing and entering the den to mark the site (Figs. 2A, 2B, 2C). This action

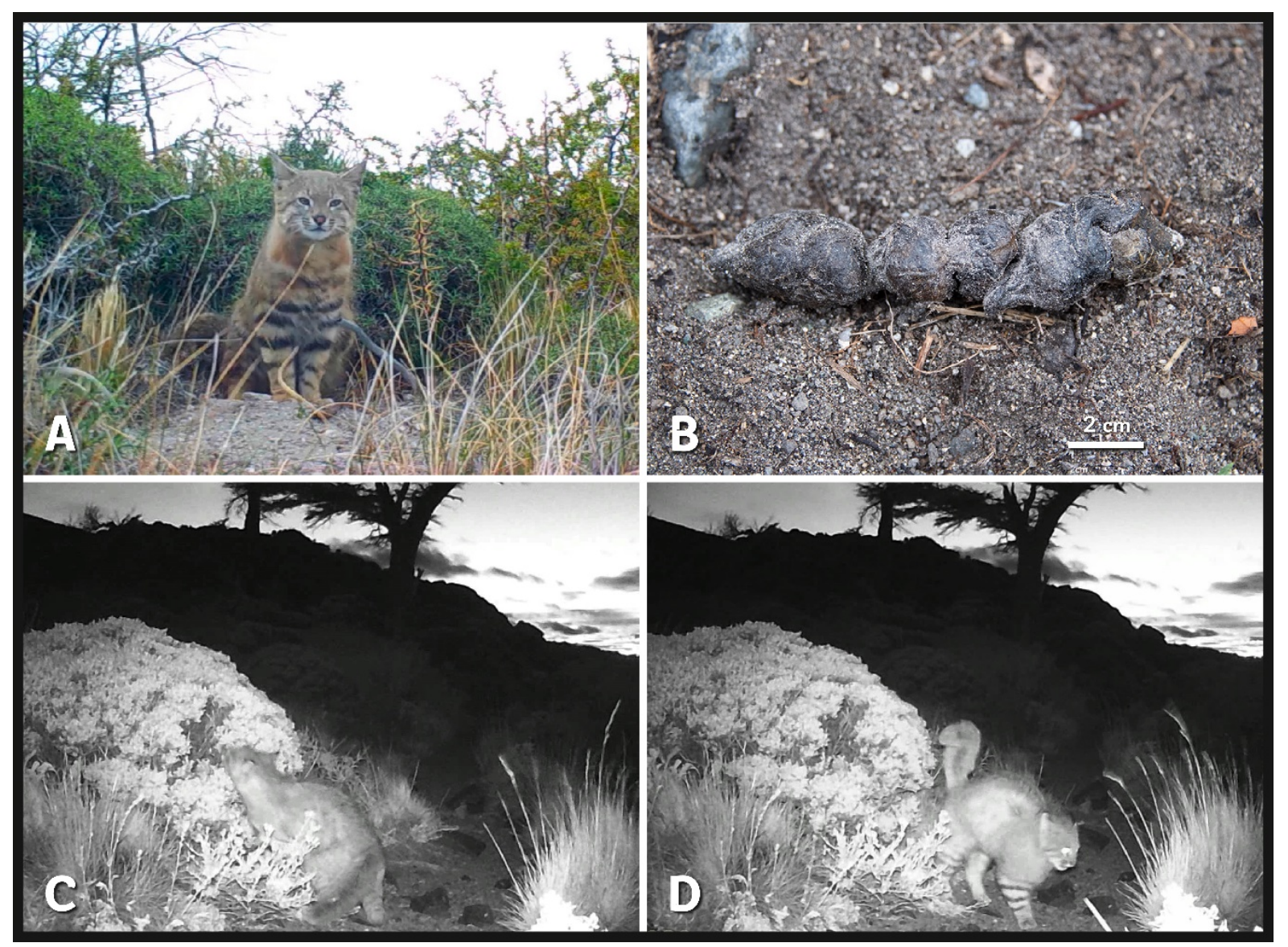

Figure 1. A) Pampas cat defecating in abandoned burrow. B) Faeces of Pampas Cat found in the burrow. C) Pampas cat sniffing. D) Pampas cat spraying. / A) Gato Colo-Colo defecando en una cueva abandonada. B) Heces de gato Colo-Colo encontradas en la cueva. C) Gato Colo-Colo olfateando. D) Gato Colo-Colo rociando orina. 
coincides with those registered by Rodgers et al. (2015) for ocelots (Leopardus pardalis Linnaeus, 1758). In this case, we could not register the feces; probably because a Conepatus chinga humboldti Gray 1837 inhabited this den (Fig. 2D). The third recorded behavior corresponds to a Pampas cat marking by urine spraying after smelling (Figs. 1C and 1D).

We present the first Colo-Colo records in the Northern Patagonia (Región de Aysén), which confirms this elusive feline in Chile near the Argentinean frontier. Confirmed records of $L$. colocola in the southern part of Chile corresponded to southern Patagonia in Región de Magallanes and Antártica Chilena (Johnson et al. 1990; Garcia-Perea 1994). We highlight the fact that no records existed since 1990 in this macro zone of the country. In addition, we recorded the first images of marking behaviour through defecation and urine spraying for the pampas cat in Patagonia. In the extreme north of Chile, it has been described that the Leopardus colocola uses small caves between rocks at the bottom of the creek or in rocky outcrops (Vega et al. 2018) as well as the sympatric Andean cat (Leopardus jacobita Cornalia 1865) (Napolitano et al. 2008;
Marino et al. 2010). Napolitano et al. (2008) documented that these species would share these caves as latrines. However, this "sharing" could be a marking behavior related to territory competition. These studies agree with our records of the Colo-Colo using dens or small caves of other carnivores such as Conepatus chinga humboldti. Thus, it is possible to infer that these species use feces as an important intra or interspecific communication for territory marking. It has documented that latrines have great potential as communication centers in felines of the Leopardus genus (Rodgers et al. 2015)

Luque-Fernández et al. (2019) report by camera traps a L. colocola in a den of burrowing owl (Athene cunicularia). These authors assume this behavior as a predatory action. According to what is reported in this work maybe it is stablishing a latrine. Probably small caves and dens have great importance in this species' spatial ecology in habitats of Patagonia grasslands. However, more studies about space ecology of this wildcat are needed in forest and grassland areas, since it has been reported that trees are often used as latrines by the genus Leopardus (Soler et al. 2009; Figueroa et al. 2018).

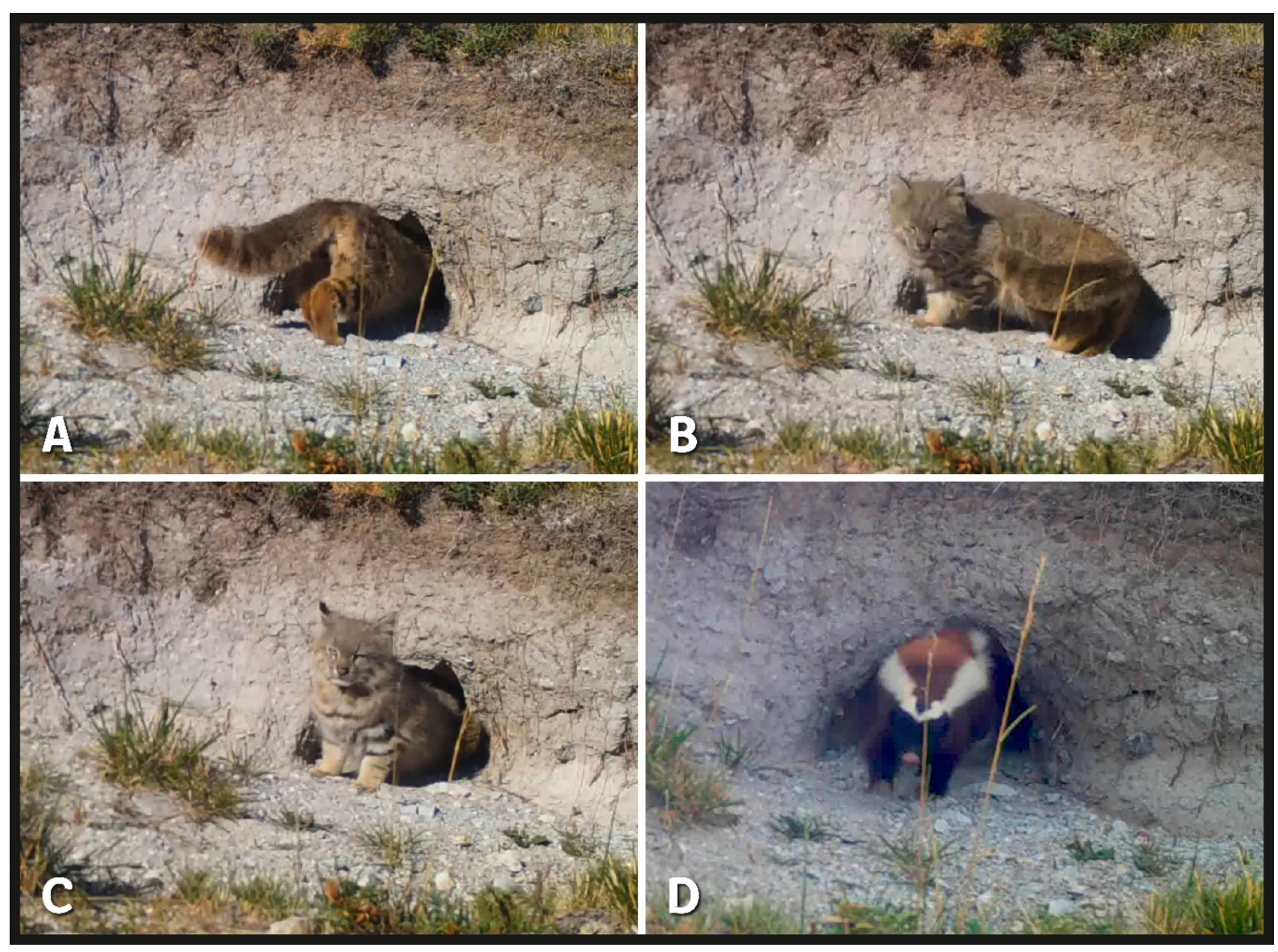

FIGURE 2. A) Pampas cat examining the cave, B) hanging out, C) defecating, E) chingue who used the cave. / A) Gato Colo-Colo examinando la Cueva, B) gato Colo-Colo dando la vuelta, C) gato Colo-Colo defecando, D) chingue que usaba la cueva. 


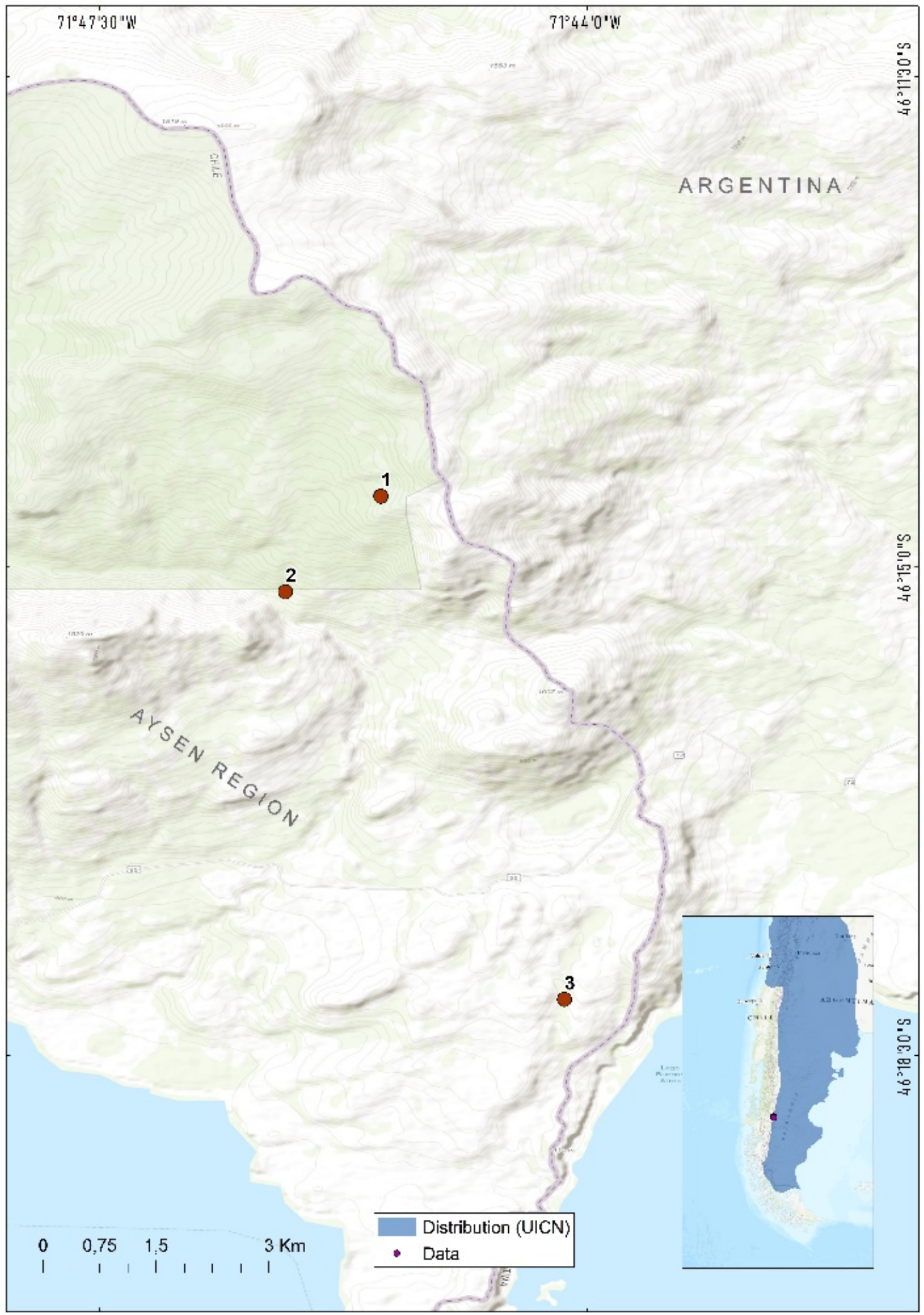

FiguRE 3. Study área, the red points represent the pampas cat records. / Área de estudio, los puntos rojos representan los registros de gato Colo-Colo. 
In our records, Leopardus colocola uses a large diameter plant like the neneo (Mulinum spinosum) to spray urine as a scent mark. Further studies are necessary to determine which plants prefer carnivores to communicate marking behavior. Indeed, the selection of plant species by carnivores for marking behavior has been sparsely documented (Piñeiro \& Barja 2012). Callahan \& Dulaney (1997) described Leopardus colocola in captivity does not scratching wood to mark its territory, assuming urine spraying could be more important than scratching in L. colocola marking behavior. Based on our reports and available literature we can asseverate that small wildcats use small caves or dens, and plants to mark its territory. It is important to highlight that at least one of the dens used as latrine was inhabited by any carnivore.

We hypothesized that there could be reciprocal benefits between the Colo-Colo, and the Patagonian hog-nosed skunk, since the burrow would serve as a refuge for the Conepatus chinga humboldti and as a latrine for the Leopardus colocola. Due to there is no temporal segregation between both species, both have night-time habits mainly (Lucherini et al. 2009; Castillo et al. 2014), and they differ in the consumed prey (Palacios et al. 2012). Even though the Colo-Colo has the potential (size and weight) to prey the Patagonian hog-nosed skunk (Oliveira \& Pereira, 2013), it would not do so because it benefits from the caves that they make.

Carnivores use urine, glandular secretions, and feces as chemical signals to inter and intraspecific communication. The roles that these scent marks play is described as territory defence, indicators of reproductive status, and preventing agonistic encounters (Eaton 1970; Smith et al. 1989; Zub et al. 2003; Wemmer and Scow 1977; Molteno et al. 1998; Broomhall et al. 2003; Smith et al. 1989; Müller and Manser 2007). In Chile, scarce knowledge about how rare and threatened small wild cats socialize in wild areas. Thus, it would be important for ecology and conservation to understand how small wildcats use defecation and urine behavior to interact with competitors, sympatric, predators and prey species.

\section{ACKNOWLEDGEMENTS}

To Eloísa Elizalde, Raimundo Elizalde y Mirco Altamirano for his collaboration in the field and the orientation of Rodrigo Villalobos, Nicolás Carusso, Eduardo Yañez and Fernando Medrano.

\section{REFERENCES}

Broomhall, L.S., Mills, M. G.L., Du Toit, J.T. 2003. Home range and habitat use by cheetahs (Acinonyx jubatus) in the Kruger National Park. Journal of Zoology 261(2): 119-128.

Callahan, P., Dulaney, M.W. 1997. Husbandry and breeding of the Pampas cat at Cincinnati Zoo and botanical garden. International Zoo Yearbook 35: 100-103.

Castillo, D. F., Luengos, E. M., Caruso, N. C., Casanave, E.B., Lucherini, M.2014.Activity patterns of Molina's hog-nosed skunk in two areas of the Pampas grassland (Argentina) under different anthropogenic pressure. Ethology Ecology \& Evolution. DOI: 10.1080/03949370.2014.953597.

Cossíos, D., Lucherini, M., Ruiz-García, M., Angers, B. 2009. Influence of ancient glacial periods on the Andean fauna: The case of the pampas cat (Leopardus colocolo). BMC Evolutionary Biology 9: 68-79.

Do Nascimento, F., Cheng, J., Feijó, A. 2020. Taxonomic revision of the pampas cat Leopardus colocola complex (Carnivora: Felidae): an integrative approach. Zoological Journal of the Linnean Society: 1-37.

Eaton, R.L. 1970. Group interactions, spacing and territoriality in cheetahs. Zeitschrift für Tierpsychologie 27: 481-491.

Figueroa, R.A., Corales, E.S., Rau, J.R. 2018. Prey of the güiña (Leopardus guigna) in an Andean mixed southern beech forest, southern Chile. Studies on Neotropical Fauna and Environment. https://doi.org/10.1080/01650521.2018.1 477032.

Garcia-Perea, R. 1994. The pampas cat group (Genus Lynchailurus Severtzov, 1858) (Carnivora: Felidae), a systematic and biogeographic review. American Museum Novitates 3096: 1-36.

Johnson, W.E., Franklin, W.L., Iriarte, J.A. 1990. The mammalian fauna of the northern Chilean Patagonia: a biogeographical dilemma. Mammalia 54(3): 457-469.

Johnson, W.E., Eizirik, E., Pecon-Slattery, J., Murphy, W.J., Antunes, A., Teeling, E., O'Brien, S.J. 2006. The late Miocene radiation of modern Felidae: $A$ genetic assessment. Science 311(5757): 73-77.

Kitchener, A.C., Breitenmoser-Würsten, C., Eizirik, E., Gentry, A., Werdelin, L., Wilting, A., Yamaguchi, N., Abramov, A.V., Christiansen, P., Driscoll, C., Duckworth, J.W., Johnson, W., Luo, S.-J., Meijaard, E., O'Donoghue, P., Sanderson, J., Seymour, K., Bruford, M., Groves, C., Hoffmann, M., Nowell, K., Timmons, Z., Tobe, S. 2017. A revised taxonomy of the Felidae. The final report of the Cat Classification Task Force of the IUCN/SSC Cat Specialist Group. Cat News Special Issue 11, 80 pp. 
Luebert, F., Pliscoff, P. 2018. Sinopsis bioclimática y vegetacional de Chile. Segunda Edición, Editorial Universitaria, Santiago, Chile. 384pp.

Lucherini, M., Reppucci, J.I., Walker, R.S., Villalba, M.L., Wursttern, A., Gallardo, G., Iriarte, A., Villalobo, R., Perovic, P. 2009. Activity pattern segregation of carnivores in the high Andes. Journal of Mammalogy 90(6): 1404-1409.

Lucherini, M., Eizirik, E., de Oliveira, T., Pereira, J., Williams, R.S.R. 2016. Leopardus colocolo. The IUCN Red List of Threatened Species 2016

Luque-Fernández, C. 2019. Diet and behavior of the burrowing owl (Athene cunicularia) in Atiquipa, an ecosystem of Lomas in the south of Peru. Biodiversitas 20(12): 137143.

Marino, J., Lucherini, M., Villalba, M.L., Bennett, M., Cossíos, D., Iriarte, A., Perovic, P.G., Sillero-Zubiri, C. 2010. Highland cats: ecology and conservation of the rare and elusive Andean cat. 581-598 pp. In: McDonalds, D.W., Loveridge, A.J. (Eds.) Biology and Conservation of wild felids.

Medina, C., Díaz, C., Delgado, F., Ynga, G., Zela, H. 2009. Dieta de Conepatus chinga (Carnívora: Mephitidae) en un bosque de Polylepis del departamento de Arequipa, Perú. Revista Peruana de Biología 16(2): 183-186.

Molteno, A.J., Sliwa, A., Richardson, P. 1998. The role of scent marking in a free-ranging, female black-footed cat (Felis nigripes). Journal of Zoology 245(1): 35-41.

Müller, C.A., Manser, M.B. 2007. Scent-marking and intrasexual competition in a cooperative carnivore with low reproductive skew. Ethology 114(2): 174-185.

Muñoz-Pedreros, A. 2010. Huellas y signos de mamíferos de Chile. Valdivia: CEA Ediciones. 122 pp.

Napolitano, C., Bennett, M., Jhonson, W.E., O’Brien, S.J., Marquet, P.A., Barria, I., Poulin, E., Iriarte, A. 2009. Ecological and Biogeographical inferences on two sympatric and enigmatic Andean cat species using genetic identification of faecal samples. Molecular Ecology 17(2): 678-690.

Nowell, K., Jackson, P. 1996. Wild Cats: Status survey and conservation action plan. International Union for Conservation of Nature and Natural Resources - IUCN. Gland Switzerland. 383 pp.

Oliveria, T., Pereira, J. 2013. Intraguild Predation and Interspecific Killing as Structuring Forces of Carnivoran Communities in South America. Journal of mammalian evolution. DOI: 10.1007/s10914-013-9251-4.
Palacios, R., 2007. Manual para la identificación de carnívoros andinos. Alianza Gato Andino, Córdoba, Argentina. 40 pp.

Palacios, R., Walker, R.S., Novaro, A.J. 2012. Differences in diet and trophic interactions of Patagonian carnivores between areas with mostly native or exotic prey. Mammalian Biology 77: 183-189.

Piñeiro, A., Barja, I. 2012. The plant physical features selected by wildcats as signal posts: an economic approach to fecal marking. Naturwissenschaften 99: 801-809.

Rodgers, T.W., Giacalone, J., Heske, E.J., Pawlikowski, N.C., Schooley, R.L. 2015. Communal latrines act as potentially important communication centers in ocelots Leopardus pardalis. Mammalian Biology 80: 380-384.

Santos, A., Campos, T., Gomes de Oliveira, T., Silveira, L., Eizirik, E. 2018. Phylogeographic analyses of the pampas cat (Leopardus colocola; Carnivora, Felidae) reveal a complex demographic history. Genetics and Molecular Biology 41(1): 273-287.

Smith, J.L.D., McDougal, C., Miquelle, D. 1989. Scent marking in free ranging tigers, Panthera tigris. Animal Behavior 37: 1-10.

Soler, L., Lucherini, M., Manfredi, C., Ciuccio, M., Casanave, E. 2009. Characteristics of defecation sites of the geoffroy's cat Leopardus geoffroyi. Mastozoología Neotropical 16(2): 485-489.

Travaini, A., Delibes, M., Ceballos, O. 1998. Summer foods of the Andean hog-nosed skunk (Conepatus chinga) in Patagonia. Journal of Zoology of London 246: 457-460.

Vega, P., Medina, D., Jara, D., Mella, J. 2018. Uso y caracterización de letrinas de gato Colo-Colo Leopardus colocolo (Molina 1782) en el altiplano de la I Región de Tarapacá, Chile. Boletín del Museo Nacional de Historia Natural (Chile) 67(2): 41-48.

Wemmer, C., Scow, K. 1977. Communication in the Felidae with emphasis on scent marking and contact patterns. 749766 pp. In: Sebock, T.A. (Ed.) How animals communicate. Indiana University Press, Bloomington.

Wolffshon, J.A. 1908. Contribuciones a la mamalojia Chilena. Revista Chilena de Historia Natural 12(3): 165-172.

Zub, K, Theuerkauf, J., Jedrzejewski, W., Jedrzejewska, B., Schmidt, K., Kowalczyk, R. 2003. Wolf pack territory marking in the Bialowieza primeval forest (Poland). Behaviour 140(5): 635-648.

Received: 14.03 .2020

Accepted: 08.03.2021 